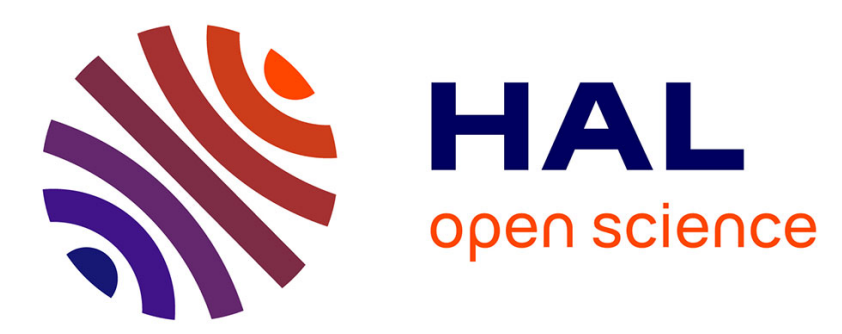

\title{
Influence of hydrogen on minority carrier recombination at dislocations and sub-boundaries in GaAs
}

A. Djemel, J. Castaing, Jacques Chevallier

\section{To cite this version:}

A. Djemel, J. Castaing, Jacques Chevallier. Influence of hydrogen on minority carrier recombination at dislocations and sub-boundaries in GaAs. Revue de Physique Appliquée, 1988, 23 (7), pp.1337-1339. 10.1051/rphysap:019880023070133700 . jpa-00245950

\section{HAL Id: jpa-00245950 https://hal.science/jpa-00245950}

Submitted on 1 Jan 1988

HAL is a multi-disciplinary open access archive for the deposit and dissemination of scientific research documents, whether they are published or not. The documents may come from teaching and research institutions in France or abroad, or from public or private research centers.
L'archive ouverte pluridisciplinaire HAL, est destinée au dépôt et à la diffusion de documents scientifiques de niveau recherche, publiés ou non, émanant des établissements d'enseignement et de recherche français ou étrangers, des laboratoires publics ou privés. 


\title{
Influence of hydrogen on minority carrier recombination at dislocations and sub-boundaries in GaAs
}

\author{
A. Djemel, J. Castaing and J. Chevallier ( ${ }^{(1)}$ \\ Laboratoire de Physique des Matériaux, CNRS Bellevue 92195 Meudon Cedex, France \\ ( $\left.{ }^{1}\right)$ Laboratoire de Physique des Solides CNRS Bellevue 92195 Meudon Cedex, France
}

(Reçu le 11 février 1988, révisé le 22 mars 1988, accepté le 24 mars 1988)

\begin{abstract}
Résumé. - Nous avons étudié par cathodoluminescence l'influence de l'hydrogène sur la recombinaison des porteurs minoritaires aux dislocations et aux sous-joints de grains dans GaAs. Ces défauts étendus ont été introduits par déformation plastique à chaud. Le caractère recombinant de ces défauts n'est pas qualitativement changé par l'hydrogène.
\end{abstract}

\begin{abstract}
We have investigated by cathodoluminescence the influence of atomic hydrogen on the minority carrier recombination at dislocations and sub-boundaries in GaAs. These extended defects have been introduced by plastic deformation at high temperature. The recombining character of these defects is not qualitatively changed by hydrogen.
\end{abstract}

\section{Introduction.}

There is a growing interest for the influence of hydrogen on semiconductor properties as recently reviewed [1]. In $\mathrm{Si}$ and $\mathrm{GaAs}$, it has been shown that the free carrier concentration is decreased as a consequence of a shallow dopant passivation effect by hydrogen [2-4]. Only limited investigation has been made on semi-insulating GaAs. On the other hand, the use of imperfect semiconductor, such as polycrystalline $\mathrm{Si}$ is increasing, boosting research on extended defects and polycrystals [5]. In order to bring information on boundaries in GaAs, we have investigated their influence on the recombination of minority carriers before and after hydrogenation.

\section{Experimental techniques.}

Semi-insulating liquid encapsulated GaAs [6] have been used in our work. The crystals were deformed in liquid $\mathrm{B}_{2} \mathrm{O}_{3}$ [7-8] to achieve high densities of dislocations [9-10], which accumulate to form subboundaries; the crystals are polygonized by plastic deformation, with typical cell sizes of a few tens of $\mu \mathrm{m}$. The microstructures have been observed by cathodoluminescence (CL) in a scanning electron microscope. The emitted light is collected by an ellipsoidal mirror and concentrated on a S2OR photomultiplier with good sensitivity in the 300$900 \mathrm{~nm}$ bandwidth.
The samples were then submitted to a R.F. hydrogen and deuterium plasma during $90 \mathrm{~min}$ at a temperature of $240{ }^{\circ} \mathrm{C}$; power between 10 and $40 \mathrm{~W}$ and pressures of $100 \mathrm{~Pa}$ were used. Using a CAMECA IMS3F system, we have performed SIMS experiments on deuterated samples in order to analyse the hydrogen diffusion depth. The penetration depth under the above plasma exposure conditions is about $3.5 \mu \mathrm{m}$.

\section{Results.}

After deformation, the cell structure is visible in the CL mode (Fig. 1). The sub-grains correspond in size to what has been observed in transmission electron microscopy [9].

Figure 2 shows the effect of hydrogen introduction on the CL intensity in the grains. The left side of the sample (dark region) has been protected from hydrogenation using a mask. The right side (bright region) has been directly exposed to the hydrogen plasma. We note a significant increase of the CL intensity in the exposed regions indicating a substantial change of the electronic properties of GaAs in the bulk or at the surface. A band to band photoluminescence efficiency increase has been previously reported after hydrogenation of lightly doped ( $n$ or $p$ type) GaAs [11]. This result has been interpreted in terms of hydrogen passivation of deep centers pre- 


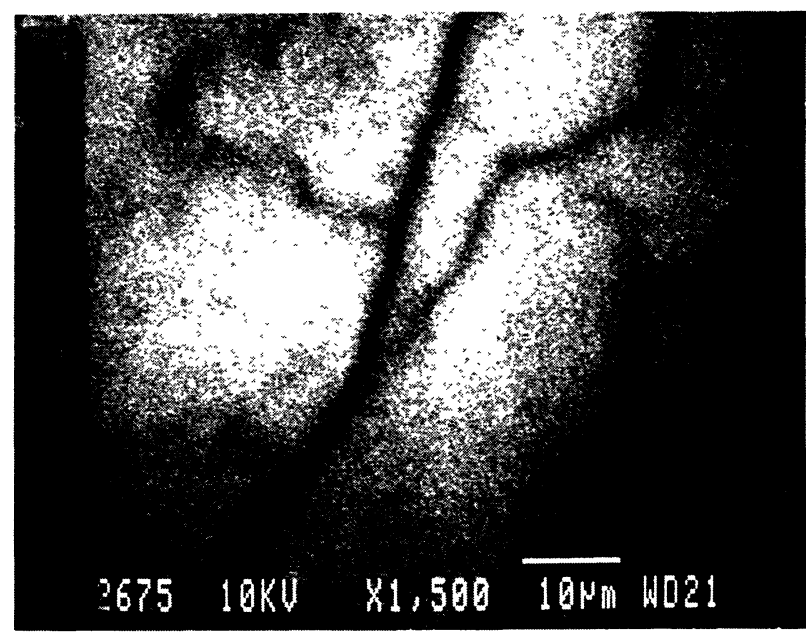

Fig. 1. - Cell structure of GaAs after deformation at $1036^{\circ} \mathrm{C}$. Applied stress : $10 \mathrm{MPa}$, total strain : $6.3 \% \mathrm{CL}$ observation without hydrogenation; beam intensity : $10^{-7}$ A.

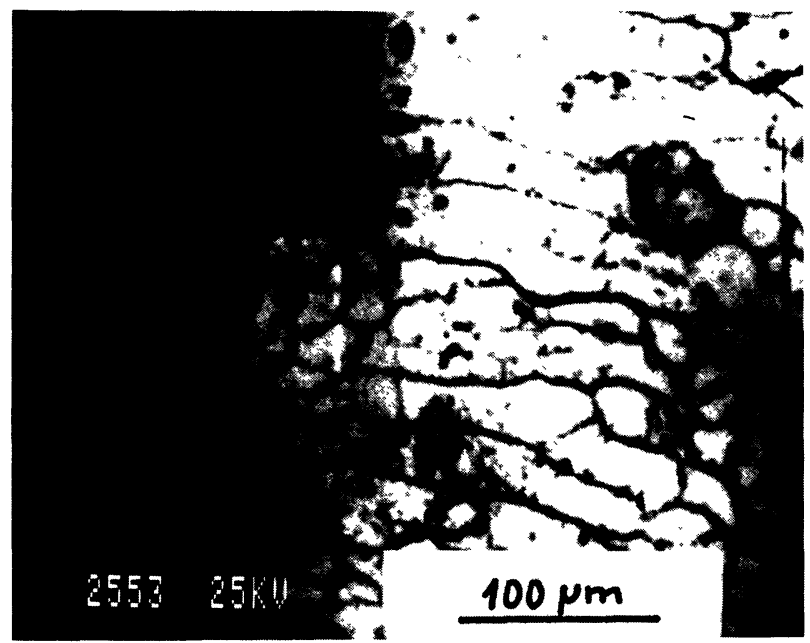

Fig. 2. - CL of deformed GaAs. The right part (bright region) has been submitted to hydrogen diffusion from the plasma. The left part has been protected by a mask and is shown as a reference (see also Fig. 1).

sent in the material. In our case, work is under way in order to know the respective contribution of the bulk and the surface to the increase of luminescence efficiency. We expect that interfaces should be similar but influenced by hydrogen. Figure 3 shows that the non-radiative character of the grain boundaries is still present after introduction of hydrogen into the material. Therefore grain boundaries do not undergo any observable passivation effect. In $\mathrm{Si}$, it has been shown that the passivation of grain boundaries by hydrogen depends on the nature of the boundaries and their thermal history [4, 12]. Here, in GaAs, black dots appear within the grains (Fig. 3), which were not observable before hydrogenation (Fig. 1). These black dots are probably due to dislocations. Knowing that the hydrogen plasmainduced defects have been detected in hydrogenated silicon [13] the origin of these dislocations appears as an open question. Either these defects exist prior hydrogenation or they appear during the plasma exposure : this question is under investigation. We must emphasize that the plasma energy does not modify the above observations.

As a conclusion, we have found that, after hydrogen plasma exposure, the luminescence efficiency from deformed $\mathrm{GaAs}$ is significantly increased. However, the dislocations generated by the deformation are not passivated by atomic hydrogen and CL black dots attributed to dislocations become observable.

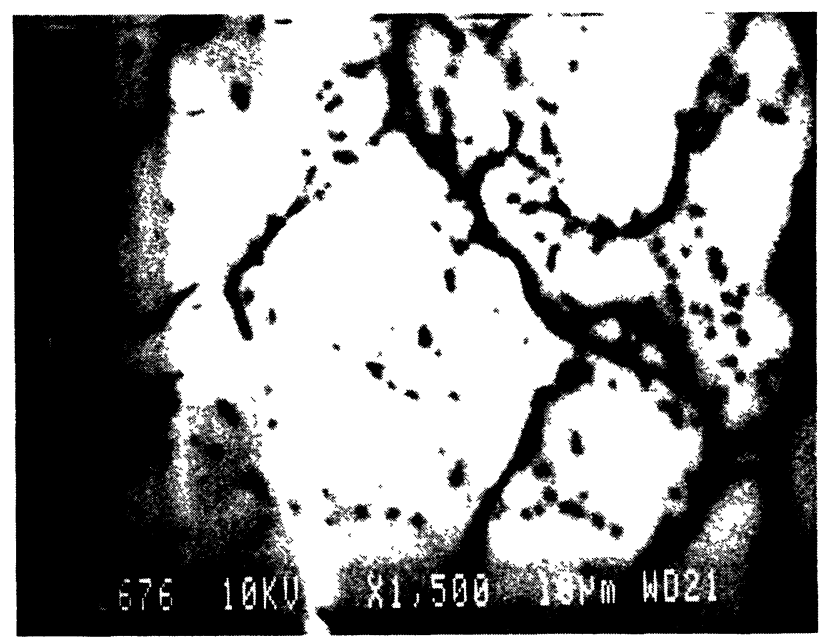

Fig. 3. - CL of deformed GaAs after hydrogenation corresponding to the right part of figure 2 , beam intensity : $10^{-8} \mathrm{~A}$.
[1] Pearton, S. J., Corbett, J. W., Shi, T. S., Appl. Phys. A 43 (1987) 153.

[2] Chevallier, J., Dautremont-Smith, W. C., Tu, C. W., Pearton, S. J., Appl. Phys. Lett. 47 (1985) 108.
[3] Johnson, N. M., Burnham, R. D., Street, R. A., Thornton, R. L., Phys. Rev. 33 (1986) 1102.

[4] Chari, A., de Mierry, Ph., Menikh, A., AUCouturier, M., Revue Phys. Appl. 22 (1987) 655 . 
[5] Maurice, J. L., Revue Phys. Appl. 22 (1987) 613.

[6] We have used Crystals Grown at L.E.P. (Limeil Brevannes) and at Thomson (L.C.R.), DusEAUX, M. and BONNET, M. are acknowledged for their cooperation.

[7] Djemel, A., CAStaing, J., Europhys. Lett. 2 (1986) 611.

[8] Djemel, A., Castaing, J., Duseaux, M., Philos. Mag. A, 57 (1988) 671.

[9] JimeneZ-Melendo, M., DJemel, A., Riviere, J. P., Castaing, J., Mater. Sci. Forum 10-12 (1986) 791.
[10] Jimenez-Melendo, M., DJemel, A., Riviere, J. P., Castaing, J., Thomas, C., Duseaux, M., Revue Phys. Appl. 23 (1988) 251.

[11] Dautremont-Smith, W. C., Nabity, J. C., Swaminathan, V., Stalova, M., Chevallier, J., Tu, C. W., Pearton, S. J., Appl. Phys. Lett. 49 (1986) 1098.

[12] Martinuzzi, S., Revue Phys. Appl. 22 (1987) 637.

[13] Johnson, N. M., Ponce, F. A., Street, R. A., Nemanich, R. J., Phys. Rev. B 35 (1987) 4166. 